DOI: https://doi.org/10.15407/techned2018.05 $: \underline{039}$

\title{
ADAPTIVE CONTROL SYSTEM OF THE FREQUENCY CONVERTER ON THE BASIS OF RESONANT INVERTER WITH NONLINEAR CONTROL
}

Journal

Publisher

ISSN

Issue

Pages
Tekhnichna elektrodynamika

Institute of Electrodynamics National Academy of Science of Ukraine 1607-7970 (print), 2218-1903 (online)

No 5, 2018 (September/October)

$39-43$

\section{Authors}

G.V. Pavlov ${ }^{\star}$, I.L. Vinnychenko**, M.V. Pokrovskiy ${ }^{\star \star *}$

Admiral Makarov National university of shipbuilding,

Heroiv Ukrainy ave., 9, Mykolaiv, 54001, Ukraine,

e-mail: pavlov.gv.nuk@gmail.com , i.l.vinnychenko@gmail.com

* ORCID ID : http://orcid.org/0000-0002-4937-1828

** ORCID ID : http://orcid.org/0000-0002-3768-1060

*** ORCID ID : http://orcid.org/0000-0002-6851-3748

\begin{abstract}
The adaptive microprocessor control system of the frequency converter based on the resonant inverter is developed, which allows, by implementing of the soft switching of power transistors, forming the low-frequency sinusoidal output voltage with low THD and, extending the operating range of the load characteristics of the converter due to the adaptive regulation. The corrected value of the relative output voltage, which is considered during the formation of the control pulses sequence, which goes to the key elements of the circuit, during the escape from the
\end{abstract}


operating range of the load characteristics of the converter, is determined. References 8 , figures 3 .

Key words: frequency converter, resonant inverter, adaptive control system, load characteristic.

Received: 05.03 .2018

Accepted: 11.05 .2018

Published: 16.08 .2018

\section{References}

1. Pavlov G.V., Vinnichenko I.L., Obrubov A.V. Frequency converter with lower THD of the output voltage. Tekhnichna Elektrodynamika. 2016. No 5. Pp. 14-16. (Rus). DOI: https://doi.o $\mathrm{rg} / 10.15407 / \mathrm{techned2016.05.014}$

2. Reznikov S.B., Bocharov V.V., Kornilov A.B. Multiphase cycloconverts with correction of power factor for power sup-ply systems of fully electrified airplanes. Trudy MAI. 2011. No 71.

(Rus) URL:

w.mai.ru/science/trudy/

(Accessed 21.03.2018).

3. Yurchenko, O.M., Gutsalyuk V.Ya., Gerasimenko P.Yu., Slyesarevskiy I.O. Model of resonant transistor voltage in-verter with low frequency pulse modulation. Tekhnichna Elektrodynamika

2011. No 1. Pp. 24 - 30. (Ukr)

4. Nazarova, N., Vinnichenko D. Electrotechnical control and current protection system of the high-voltage pulse-current generator. Proc. of 2017 IEEE First Ukraine Conference on Electrical and Computer Engineering (UKRCON). 2017. Pp.

574-577. DOI: 
https://doi.org/10.1109/UKRCON.2017.8100307

5. Pavlov G., Vinnichenko I., Pokrovskiy M. Research of the interrelationship between the frequency converter on the basis of the resonant inverter with nonlinear control power unit parameters and its load. Proc. of 2017 IEEE First Ukraine Conference on Electrical and Computer Engineering (UKRCON). 2017. Pp. 554-559. DOI: https:// doi.org/10.1109/UKRCON.2017.8100300

6. Pavlov G., Obrubov A., Vinnichenko I. The linearized dynamic model of the series resonant converter for small signals. Proc. of IEEE 2nd International Conference on Intelligent Energy and Power Systems g/10.1109/IEPS.2016.7521879

(IEPS). 2016. Pp. 221-225. DOI: https://doi.or

7. Shi L., Shan C., Wu X., Zhao N. Comparison of solid-state frequency converter and rotary frequency converter in $400 \mathrm{~Hz}$ power system. Proc. of International Conference on Electrical Machines and Systems. 2011. Pp. 1-5.

8. Wang Chien-Ming, Guan-Chyun Hsich. A Series-Resonant DC/AC Inverter for Impedance-Load Drives. IEEE Transactions on power electronics. 2001. Vol. 16. No 3. Pp. 325-334. DOI: https://doi.org /10.1109/63.923764

$\underline{\text { PDF }}$ 